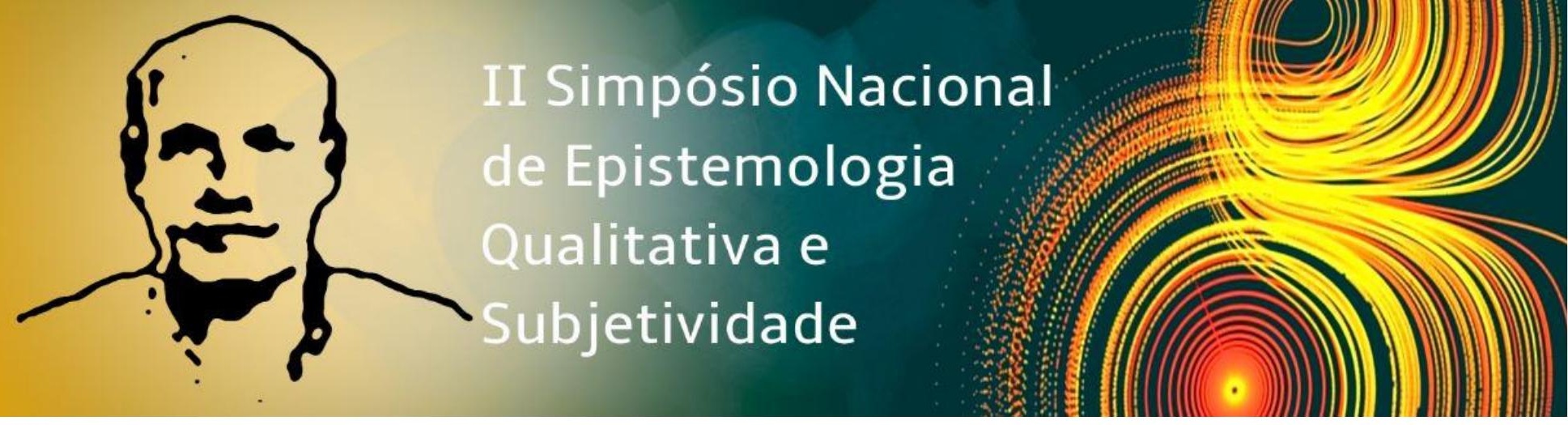

Eixo temático: Subjetividade e saúde humana

\title{
Comunidade, saúde mental e subjetividade: o tornar-se sujeito no território
}

Letícia Marques, Uniceub, leticiasilvamarques97@gmail.com

Daniel Goulart, Uniceub, danielgoulartbr@gmail.com

\section{Resumo}

Esta apresentação tem como objetivo discutir as ideias centrais e os resultados parciais de uma monografia em construção para a obtenção do título de psicóloga, que versa sobre a articulação entre comunidade, saúde mental e subjetividade, enfatizando o tornar-se sujeito no território, a partir da perspectiva da Teoria da Subjetividade desenvolvida por Fernando González Rey. Primeiramente, será feita uma discussão sobre o surgimento da Psicologia Social Comunitária na América Latina e como esse campo buscou deselitizar a profissão do psicólogo, buscando melhoria em suas condições de vida. Pretende-se discutir como esses espaços comunitários são propícios à inclusão social e à promoção de um acolhimento orientado ao empoderamento do indivíduo (Scheneider \& et al, 2016). Como discutido por González Rey (2014), a comunidade é um tecido social complexo, que possui múltiplos processos simbólicos em sua gênese e que passam a ter uma presença ativa na vida de seus integrantes, podendo favorecer processos de emergência de sujeitos. Nessa ótica, os espaços comunitários são geradores de sentidos subjetivos, podendo representar subjetividades sociais férteis para a gênese de novas configurações subjetivas individuais e sociais. O indivíduo, a partir dessa perspectiva teórica, é ativo até em momentos de sofrimento, de modo a ser permanentemente possível gerar novos espaços de subjetivação para além do sofrimento cristalizado (González Rey e Martinez, 2017). Em saúde mental, a rede pública oferece um cuidado a partir desse fazer comunitário. O serviço público da saúde mental não é o único modo para o cuidado, demonstrando a necessidade da criação de outros espaços sociais comunitários. - tal como a organização da sociedade civil onde está pesquisa está sendo feita. Nosso objetivo é. Compreender produções subjetivas de uma organização comunitária de saúde mental, enfatizando processos de emergência do sujeito A pesquisa está sendo realizada a partir dos princípios da Epistemologia Qualitativa e da metodologia construtivointerpretativa de González Rey (2017). Os participantes são integrantes de um grupo de ouvidores de vozes. Os instrumentos utilizados têm sido a dinâmica conversacional.

Atualmente, encontramos em fase inicial de campo. No entanto, pensamos que o II Simpósio Nacional de Epistemologia Qualitativa e Subjetividade constitui-se em espaço fecundo para discutir a construção de informação parcial, que estará então disponível para análise. Essa apresentação visa discutir os resultados parciais da experiência em um grupo de Ouvidores de 


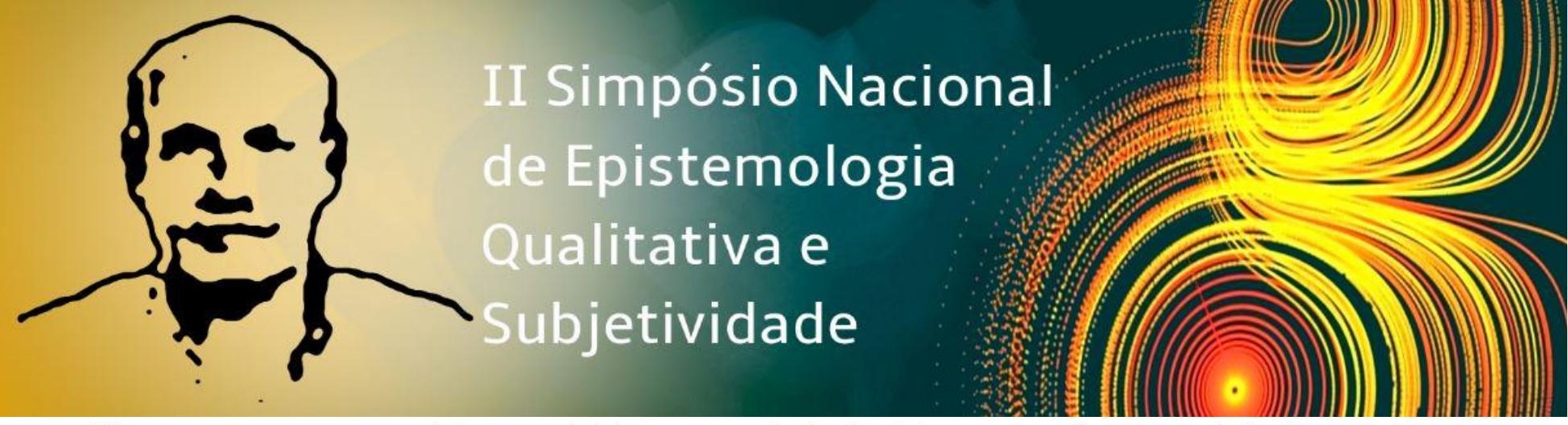

Vozes em um espaço social comunitário e os possíveis desdobramentos dessa convivência ao pensar no tornar-se sujeito.

Palavras chave: Comunidade, subjetividade social, saúde mental

\section{Referências}

González Rey, F.L. (2014). Dilemas epistemológicos actuajes en psicologia comunitária

González Rey, F.L.; Martínez, A. M. (2017). Subjetividade: Teoria, epistemologia e método. São Paulo: Alínea.

Schneider, D.R, Oltramari L, Budde C, Silveira A.L, Silveira S (2016) A clinica na comunidade: uma experiência de intervenção intersetorial para adolescentes em situação de vulnerabilidade psicossocial. Cadernos Brasileiros de Saúde Mental, v.8, 2016. 